\title{
Connecting Knowledge for Text Construction through the Use of Graphic Organizers*
}

\author{
El Uso de Organizadores Gráficos para la Construcción \\ de Textos y la Creación de Conocimiento
}

\author{
Elsy Camila Reyes \\ English teacher, \\ Colegio Nuestra Señora de Pilar Sur \\ E-mail: camilare23@yahoo.com
}

\begin{abstract}
This study analyzed how basic level students comprehend short descriptive texts and rewrite their texts through the use of graphic organizers (GOs). The research was built upon the qualitative research paradigm with the inclusion of descriptive and introspective approaches. The study was carried out at a prestigious private school in Bogotá, Colombia, with basic English level II sixth graders. Data was gathered through focus groups, GOs, and students' documents. The results of the study demonstrated that students made connections with previous knowledge acquired at school as part of the curriculum or at home as part of their daily experiences. Participants organized the information in principal and supporting ideas in order to comprehend and rewrite their texts. According to the results, the study found that learners have previous ideas or knowledge that let them complement, organize, or re-direct a given topic.
\end{abstract}

Key words: texts reconstruction, graphic organizers, previous and new knowledge connections

\section{Resumen}

En este estudio se analizó cómo los estudiantes de inglés básico en grado sexto fueron capaces de comprender textos descriptivos cortos y verse ellos mismos como productores de textos haciendo uso de organizadores gráficos (OG). La investigación se realizó con base en el paradigma cualitativo con la inclusión de los enfoques descriptivo e introspectivo. El estudio se llevó a cabo en una prestigiosa escuela del sector privado en Bogotá, Colombia, con estudiantes de grado sexto del nivel básico de inglés. Los datos fueron recolectados usando tres instrumentos: grupos focales, organizadores gráficos y los documentos de los estudiantes. Los resultados del estudio demostraron que los estudiantes hacen conexiones entre el conocimiento previo que pudo ser adquirido en la escuela, como parte del currículo, o en la casa, como parte de su experiencia cotidiana. Los participantes organizaron la información en ideas principales e ideas secundarias con el propósito de comprender la lectura así como para re-escribir sus nuevos textos, lo cual permitió concluir que los estudiantes tienen ideas o conocimiento previo que les permite complementar, organizar, o re-direccionar un tema dado.

Palabras clave: Reconstrucción de textos, organizadores gráficos, conexión entre conocimiento previo y nuevo

Received 16-Nov-10/ Accepted 24-Jan-11

* Research Article associated with the project titled "Graphic Organizers and the reconstruction of texts" carried out at the M.A. program in Applied linguistics to EFL. Universidad Distrital Francisco José de Caldas 


\section{Introduction}

Reading should be considered more than just decoding information from a text. Reading should be addressed as a cognitive process that implies reading comprehension, text analysis, and text reconstruction. Graphic organizers are one way to improve reading comprehension and writing skills in order to help students transition from readers to writers. Although the Ministry of Education of Colombia (2005) has set standards for English language teaching, each school is allowed to organize its curriculum as they consider necessary or appropriate by taking into consideration its population needs. Some schools track English language teaching into proficiency levels such as basic, intermediate, and advanced. This kind of level organization restricts students at the basic levels in reading comprehension and writing production. Students at the basic levels believe they are unable to write or express themselves in the English language. These students believe they are in the English basic level for pure grammar structure. I wanted to show my basic level students that they were capable of reading, analyzing, and comprehending short descriptive texts. I also wanted my students to see themselves as texts producers. Overall, I wanted to analyze participants' responses to the texts in terms of understanding, making connections, and organizing information.

In order to account for these aspects, the study posed the following main question: How do students reconstruct their texts when using graphic organizers? Likewise, there was a supporting question which attempted to describe how students connect previous and new knowledge. This question was stated as follows: What do written productions from students show the ELT community about students' connections with previous knowledge? Based on the research questions two objectives were posed: 1) to explore the use of graphic organizers while reconstructing texts and 2) to examine the kind of information students use to reconstruct texts.

This research took place at a prestigious private high school in Bogota where English language teaching is tracked into two levels: advanced and basic. Taking into account that my participants were in the English basic course, and only students who are able to express themselves using the English language were in the advanced course, I focused my attention on the literacy process.

Reading and writing are cognitive processes that involve not only linguistic knowledge but also cultural, social, scientific, and daily experience knowledge (Lerner, 2001). In my opinion, readers should not focus just on reading comprehension; they should go beyond the text. In order for reading to be a cognitive process, a person who reads and understands a text must express his/ her feelings or ideas about his/her interpretations. In this paper I will present a discussion of the theoretical constructs that guided my research, the methodology followed in this study, and, finally, the outcomes and conclusions.

\section{Literature Review}

This study includes the following theoretical aspects: 1) text reconstruction allows students not only to obtain new and different information but also to connect concepts and produce their own knowledge (Goodman, 1996) while taking into consideration the relationship between input and output and 2) graphic organizers are tools to help students understand, classify, organize, and connect information.

Different studies about literacy have been conducted in order to analyze writing and reading processes, acquisition, and development. When one examines the literature about reading, one realizes that this concept has different meanings. Some believe that readers only identify letters, words, sentences, and phrases; others think that reading is related to understanding the meaning 
of the text (Goodman 1996). Various authors see reading as a process of decoding, identifying information, and understanding a message (Alderson, 2000).

Taking into account the purposes of this study, I would consider reading a process of interaction among thought, language, and personal experiences or existing knowledge. After reading Carretero (2005), I conclude that people can construct their own perceptions and knowledge of the world from their practices, experiences, and reflections on those experiences. When learners face new knowledge, the new information becomes meaningful and easier to retain if they connect the new information with previous knowledge and experience. According to Goodman (1996), reading is a cognitive process because meaning is created from a text while reading it. Reading also involves constructing relationships among concepts through previous and new knowledge. Goodman (1996) defines reading and writing as comprehending and comprehension. The author argues that comprehending "is the process of making sense of written language" while comprehension "is the resulting meaning" ( $p$. 109). In other words, when this researcher talks about comprehending, he refers to the "process" while comprehension is related to the "product". This project focuses not only on the process of reading, analyzing, and understanding texts, but also on the product: text reconstructions that include previous experiences and knowledge, as well as using graphic organizers to relate and organize information and ideas. In this study both concepts were considered. Students played two roles, one as readers who read, analyzed, and interpreted the text, and the other as writers, who produced texts based on prior knowledge and new information they acquired.

\section{Text reconstruction}

Text reconstruction can be addressed both as oral or written production. White and
Arndt (1996) show that through writing people can share thoughts and feelings, discuss their ideas with others, and argue with the purpose of contributing, modifying, and/or complementing the reader's personal or previous ideas. By including activities that let students express their emotions, express their point of view, or share their insights with others in a foreign teaching/ learning context, they will have the opportunity to create their own texts and communicate their thoughts. Goodman (1996) refers to the text reconstruction process as comprehension, which is related to the result: the product created by students after reading a text.

According to Omaggio (1993), writing can be seen from two perspectives "as a support skill and as a communicative art" (p. 291). The former refers to language code recognition, while the latter refers to the use of writing for expressing. This study is focused on writing as a support skill. Omaggio (1993) mentions the category "writing down" that focuses on the reproduction or copying of the studied or learned material. In this study the research participants reproduced texts based on a given workshop article. They also copied information from the Internet. This process was a beginning writing stage as the participants were in the second English course in the basic level.

Readers have previous knowledge and ideas that influence or complement the analysis and understanding of a message. We should bear in mind that each person has a social, cultural, educational, and life background that has an effect on his/her perceptions, thoughts, and analysis. In order to reconstruct, rewrite, or retell a text, people must organize all the information they want to include as part of their comprehending process. By organizing information, learners are able to select, classify, and relate information they are interested in incorporating into their writing process. 


\section{Graphic organizers}

Graphic organizers (GOs, henceforth) have been defined by different authors according to the uses they have given them. GOs are considered schemata, tools, learning strategies, summaries, or diagrams that help organize information (Campos, 2005). DiCecco and Gleason (2002) define GOs as "visual portrayals or illustrations that depict relationships among the key concepts taken from the learning task" (p. 307). They use GOs as comprehension tools for participants to relate information. Buzan (1996) observed that GOs help users organize as well as create connections between concepts. By using GOs, people identify main and secondary ideas, learn how to categorize information by connecting concepts, and develop logic, imagination, and creativity (Campos, 2005).

In this research project GOs were used to identify the function of each system in the body, the organs involved, and the relationship among presented concepts. The intention was not to work based on the text's structure, but instead for students to identify main and supporting ideas in order to establish relationships among the different concepts. Students were asked to include information in the GOs they considered relevant or most important. By using GOs, students could improve not only their reading comprehension but also their text reconstruction.

\section{Methodology}

This study was carried out at a prestigious private school in Bogotá, Colombia, with English basic level II students. Students were in sixth grade and between ages 10 and 11 . The research was built upon the qualitative research paradigm. Some of the data gathered reflected participants' thoughts and insights. Wallace (2002) states that a "qualitative (study) is used to describe data which are not amenable to be counted or measured in an objective way, and are therefore subjective" (p. 38). This is also an introspective study because students' rewritten articles, their previous knowledge about the topic studied, and the way participants organized information were analyzed.

The instruments used to gather the data were documents, students' written productions, pre-graphic and post-graphic organizers, and pre-focus and post-focus groups.

\section{Data gathering}

In the data analysis process key aspects to analyze were participants' insights about their previous ideas and knowledge, the acquisition of new concepts or ideas, connections between previous and new knowledge, information identification, and relations and organization. The GO documents were used to check, evaluate, and analyze students' text organization.

GOs should be considered documents because they were students' productions as well. GOs provided information on how students organized information before and after each workshop. In this qualitative study pre-GOs were used in order to find out what information students knew about the topic and post-GOs were used to examine the information they used to reconstruct texts.

The focus groups were used as a stage to spotlight students' oral reports about their own reading, analytical, and rewriting processes. It was necessary to include instruments that showed students' thoughts, ideas, and insights because this is an introspective study; hence, participants' voices must be present. Bearing in mind that students interact during the pre-focus group and post-focus groups, it was noted that research participants' knowledge and ideas could be affected or reconstructed. The pre-focus groups were carried out before each workshop in order to identify participants' prior knowledge. Postfocus groups were carried out after students had rewritten their texts in order to see if they had 
made connections between knowledge known and new knowledge.

\section{Validity}

The triangulation technique was used in order to have different perspectives about the same topic. Burns (2001) says that "the aim of triangulation is to gather multiple perspectives on the same situation being studied" (p. 163). She also argues that having the same results using different research methods is an effective way to validate one's findings.

According to Brown (2002), different methods can be used in order to validate the design, application, and analysis of an interview (the focus group in this case). Face validity and content validity were applied in this project. Face validity refers to the stage before applying the interview. Brown (2000) suggests applying the interview before going to the research group. Before the true research began the workshops, interviews, and surveys were applied to six sixth graders from an advanced level English class.

Content validity is related to the interview plan. The researchers have to take into account the main constructs of the project in order to design the interview. This technique is divided into two approaches: descriptive approach and expert rating approach. The latter was included in this study. The pre-focus groups and post-focus groups were designed and tested with the thesis advisor and colleagues at the masters program. Through discussions and taking into account peers' suggestions, the questions were refined to be more clear and coherent as related to the research problem. After these steps, the pre-focus group was piloted. The piloting showed if the questions posted to the first pre-focus group were appropriate not only to the study but to the research participants' age. The questions used for the first pre-focus group were too formal and technical, which made the interview difficult to understand. The piloting showed it was necessary to create a less formal interaction, a conversation that permitted students to express their ideas freely.

\section{Findings}

The data analysis process was carried out to answer the initial questions of this research project. Two aspects were inquired about: what could be inferred from students' connections with previous knowledge and the way students rewrite texts using GOs to organize and classify information.

Through data analysis it was possible to identify commonalities and relationships among different concepts. The following tables are used to identify and create categories by grouping the information homogeneously (Lankshear and Knobel, 2004). After organizing the data, the following categories and sub-categories emerged:

Table 1: Categories

\begin{tabular}{|l|l|}
\hline \multicolumn{1}{|c|}{ CATEGORIES } & \multicolumn{1}{c|}{ SUBCATEGORIES } \\
\hline \multirow{3}{*}{ Declarative or previous knowledge } & School knowledge \\
\cline { 2 - 2 } & Daily knowledge \\
\cline { 2 - 2 } & Acquired knowledge \\
\cline { 2 - 2 } & Making connections \\
\hline Knowledge co-construction & Knowledge clarification \\
\hline
\end{tabular}


Two categories emerged from the data analysis: Declarative or previous knowledge and Knowledge co-construction.

The first category, declarative knowledge, and its four subcategories refer to information accumulated in long term memory. Declarative knowledge consists of consciously known facts or previous knowledge. There are other aspects related to this general idea that are recognized as subcategories: school knowledge, daily experiences, and acquired knowledge. Gökler et. al. (2006) showed that student knowledge comes from school texts and daily experiences that let them make connections with new concepts. Moss (2004) also comments about personalization, or how students connect the text with their lives.

From the second category, knowledge coconstruction and its sub-category knowledge clarification, it was evident that participants were always shaping and changing their knowledge. Learners had discussions among themselves, expressed their points of view, and mediated. According to the literature, learners bring past experiences and prior knowledge to the classroom and use these to connect to new ideas or concepts.

\section{Declarative or previous knowledge}

The analysis of the information showed that participants categorized the information by identifying or selecting main and supporting ideas. Students also used other texts as a guide or model and mixed different information in order to rewrite their texts; in other words, students included their previous ideas, concepts acquired during the research implementation, their classmates' ideas, information provided by the workshop's article, and information they found in other sources. Students' mentioned that the GOs were useful tools to classify, categorize, and connect information.

However, GOs were not the only tool used for organizing information. Sometimes participants did not use the GOs as an instrument for planning and preparing their writing.

Sofia and Luna talked about their previous (or declarative) knowledge related to the brain and heart by describing the idea they had about each system. This information was used to define and support the first category: declarative or previous knowledge.

Table 2: Declarative knowledge

\begin{tabular}{|c|c|}
\hline $\begin{array}{l}\text { SOFIA - FOCUS GROUP INTERVIEW } \\
\text { "YOUR AMAZING BRAIN" }\end{array}$ & LUNA - HEART AND CIRCULATORY SYSTEM \\
\hline $\begin{array}{l}\text { S: well ehh... there are different kinds of nervous } \\
\text { systems, the central nervous system, autonomous } \\
\text { nervous system... ehh } \\
\text { T: peripheral? } \\
\text { S: that's right peripheral... the nervous system is } \\
\text { made of ehh... the brain, cerebellum, brainstem } \\
\text { and the spinal cord... }\end{array}$ & $\begin{array}{l}\text { L: The circulatory system is everything that transports } \\
\text { the blood... all the veins that are connected to the } \\
\text { heart... ehh through all the body... it pumps blood } \\
\text { mainly to the heart... it is the one that needs more } \\
\text { blood because if the heart does not work it could be } \\
\text { end in a heart attack. }\end{array}$ \\
\hline
\end{tabular}

School knowledge is knowledge acquired at school through language mediation. It includes oral cathedra, reading activities, conferences, and video conferences, among others (Gökler et. al.
2006). Luna and Sofia commented how they learned about the immune system in their previous school and in a class called Transformaciones Energéticas (Energy Transformations). 
Table 3: School knowledge

\begin{tabular}{|l|l|}
\hline \multicolumn{1}{|c|}{ LUNA - IMMUNE SYSTEM } & \multicolumn{1}{c|}{ SOFIA - IMMUNE SYSTEM } \\
\hline $\begin{array}{l}\text { I learnt it ehh because in my previous school I did a paper about } \\
\text { the cell... ehh and i had photocopies from a science book } \\
\text { and there I have all the components about the cell; so there it } \\
\text { says that the cell is like a defense for the body... also as Sofia } \\
\text { mentioned in the "transformaciones energéticas" class we could } \\
\text { see how the body can regenerates the skin... how the cell work } \\
\text { to defense it and how the blood remove bacteria... }\end{array}$ & $\begin{array}{l}\text { paper about the cell... in "transformaciones } \\
\text { energéticas" class... it was about the body } \\
\text { and there I talk about the cell... ehh in that } \\
\text { way I learnt the things that I know about the } \\
\text { cell. }\end{array}$ \\
\hline
\end{tabular}

Daily experiences help obtain knowledge outside the school. This knowledge is mediated through language but does not belong in a school environment. It could be obtained at home through parents' mediation, TV programs, home reading, or Internet information (Gökler, et. al., 2006). Participants showed how daily experiences shaped their knowledge. Luna commented about other settings, different from school, where she acquired heart and circulatory system knowledge. During the third focus group "Lungs and respiratory system", Laura, Sofía, and Alex explained how they had acquired knowledge related to the respiratory system.

Table 4: Daily experiences

\begin{tabular}{|l|l|}
\hline \multicolumn{1}{|c|}{ LUNA } & SOFÍA KNOWLEDGE RELATED TO THE RESPIRATORY SYSTEM. \\
\hline Seeing movies... ehhh watching Nat Goe & I learnt it in a Nat Geo documentary... and in the movie "increible \\
ehhh and in Discovery channel I also saw & maquina humana" (incredible human machine) that shows the \\
videos about the human body & different human systems... nervous system, circulatory system... \\
& so, thanks to the things that I saw in the movie I learnt about the \\
& systems. \\
\hline
\end{tabular}

Acquired knowledge is knowledge students report as obtained knowledge, which came from each workshop, the readings or other sources. Below one can see examples of acquired knowledge. Laura mentioned what she learned after the second workshop, "Your heart and circulatory system", and Juan discussed the concepts and knowledge he learned from reading about the respiratory system.

Table 5: Acquired knowledge

\begin{tabular}{|l|l|}
\hline \multicolumn{1}{|c|}{ LAURA } & \multicolumn{1}{c|}{ JUAN } \\
\hline T: $\quad \begin{array}{l}\text { What did you learn about the heart and the } \\
\text { circulatory system? }\end{array}$ & T: $\quad \begin{array}{l}\text { What did you learn about the respiratory } \\
\text { system? }\end{array}$ \\
$\begin{array}{c}\text { Laura: I learnt that the heart has four chambers... two } \\
\text { in the upper part and two in the lowest part... } \\
\begin{array}{l}\text { and that each one plums blood to the lungs } \\
\text { and the rest of the body }\end{array}\end{array}$ & $\begin{array}{c}\text { Juan: I learnt that... about its parts, the ramifica- } \\
\text { tions... and that the alveoli are covered of... } \\
\text { that all the bronchioles... the oxygen that } \\
\text { passes there goes to the alveoli. }\end{array}$ \\
\hline
\end{tabular}


The sub-category Making Connections refers to the process of associating two or more things from students' previous knowledge and in this case, with new, learned, or acquired concepts.

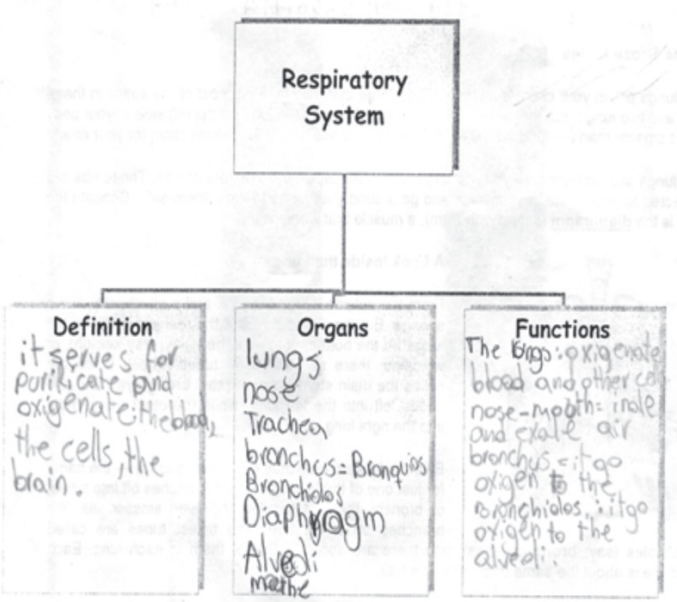

Juan used the information contained in the GOs to write his article. In Juan's article, he wrote information about the involved organs and their functions, which he had prepared in the pre-graphic organizer. This showed how student's used GOs to classify and organize information to
In the following samples, taken from the third workshop, one can see how Juan organized the information using the provided GOs.

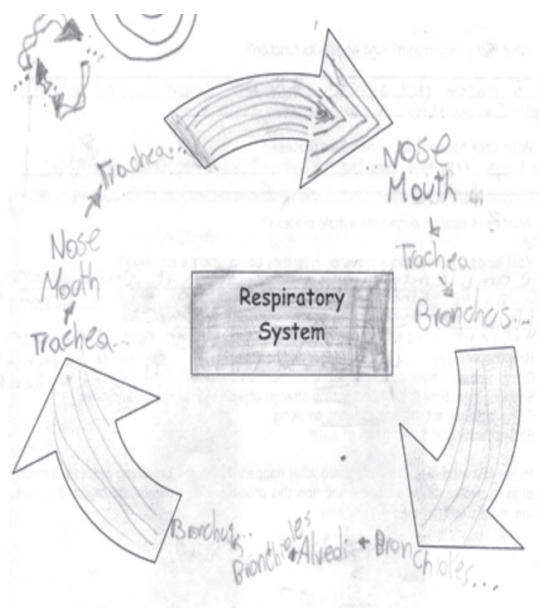

rewrite a text. The second paragraph of Juan's respiratory system article illustrates how he includes information contained in his post reading GO.

The next sample was taken from Juan's respiratory system article.

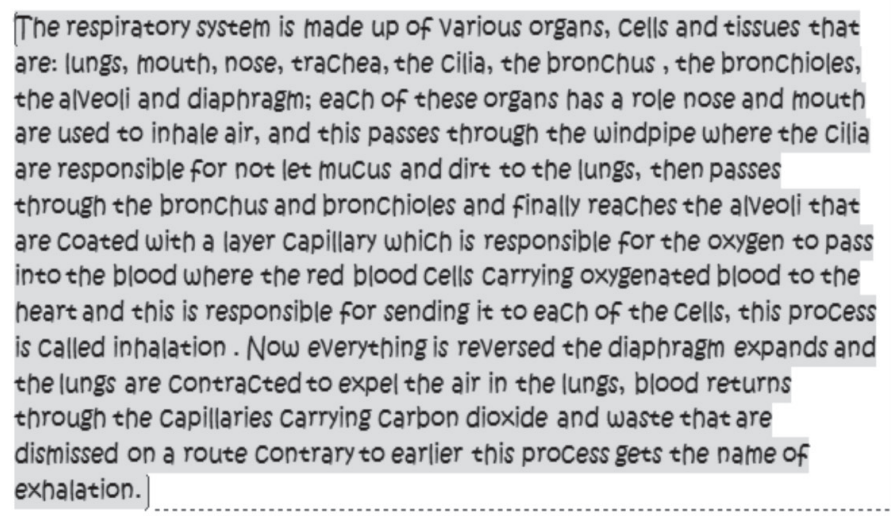

The respiratory system is made up of various organs, cells and tissues that are: lungs, mouth, nose, trachea, the cilia, the bronchus, the bronchioles, the alveoli and diaphragm; each of these organs has a role nose and mouth are responsible for not let mucus and dirt to the lungs, then passes through the bronchus and bronchioles and finally reaches the alveoli that heart and this is responsible for sending it to each of the cells, this process is called inhalation. Now everything is reversed the diaphragm expands and through the capillaries carrying carbon dioxide and waste that are dismissed on a route contrary to earlier this process gets the name of exhalation.

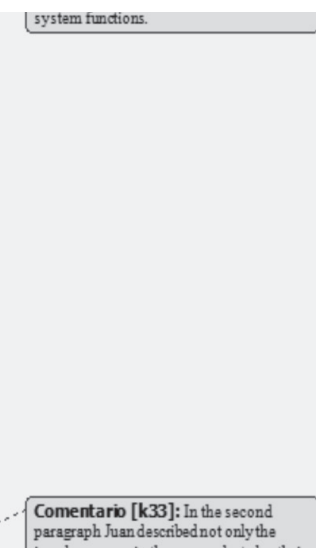

Research participants used their prior ideas and previous knowledge as a starting point for rewriting their texts. They also included aspects mentioned by other participants during the development of the pre and post-focus groups.
There are three examples related to the sub-category Making Connections. In the first example, Laura said she complemented the topic with another subject. This showed that Laura was using previous school information. In 
the second, Laura and Luna made a connection with a previous workshop (heart and circulatory system), showing they were using previous knowledge. In the third sample Luna mentioned her previous school and connected this topic with a subject she took and material she had read.

Table 6: Making connection

\begin{tabular}{|l|l|l|}
\hline LAURA - NERVOUS SYSTEM & LUNA - IMMUNE SYSTEM & LUNA - IMMUNE SYSTEM \\
\hline I complemented... because we & Ehhh the differences between the white & I learnt it ehhh because in my \\
have studies this topic about the & and red cells ... ehh... the red cells & previous school I had to do a \\
brain in another class... So, we've & carry and the white defend. I also ehh & paper... about the cell and the \\
already had some basic informa- & I didn't see so much importance to & teacher gave us some copies \\
tion to start studying about the & the immune system... but I realized & from a science book... and there \\
brain. & that without it we can't live because it & I have all the components about \\
& $\begin{array}{l}\text { protect us against bacteria and viruses } \\
\text { that arrive to our body. }\end{array}$ & $\begin{array}{l}\text { the cell that is a kind of defense } \\
\text { for the body. }\end{array}$ \\
\hline
\end{tabular}

\section{Knowledge co-construction.}

Knowledge co-construction refers to ideas or facts that students construct through dialogue or discussion during focus groups or class development. This category consists of one subcategory: Knowledge Clarification.

Knowledge clarification is when students have previous knowledge but after mediation (class, reading, conference, or discussion), they change their mind because a completed study of the concept made them realize they had a misconception or incomplete information about the concept (Gökler et. al. 2006).

During the third post-focus group Laura and Sofia mentioned the concepts they had re-learned because of a previous misconception related to the respiratory system. These two samples illustrate the way participants clarified concepts after they had read the different articles. This showed that it is possible to change a previous perception and build new knowledge based on new ideas or knowledge.

Table 7: Knowledge co-construction

\begin{tabular}{|c|c|}
\hline ALEX AND JUAN & LAURA AND SOFIA \\
\hline $\begin{array}{l}\text { Al: I knew about the valves but... I didn't know about } \\
\text { their functions... I also learnt about the veins and } \\
\text { the artiries... the veins transport blood from the } \\
\text { heart to the body... no... no it's the other way } \\
\text { around the arteries carry blood from the heart } \\
\text { S: [from the heart to the body... and the veins... } \\
\text { from the body to the heart. } \\
\text { J: I basically learnt about the differences between the } \\
\text { arteries and vein because I thought it was on the } \\
\text { other way that veins transport blood to the body. }\end{array}$ & $\begin{array}{l}\text { L: As Juan said... I laernt that the lungs... this thing } \\
\text { about the capillaries... OK the parts... bronchia, } \\
\text { bronchiolies, alveoli and the trachea... I thought } \\
\text { that the lungs worked only with the heart and that } \\
\text { there was not any other part. } \\
\text { S: Yes I learnt the same as Laura and Juan... about } \\
\text { the respiratory system parts and I also thought } \\
\text { that the lungs and the heart work together without } \\
\text { any other organ the same. }\end{array}$ \\
\hline
\end{tabular}


Students also posed questions related to the reading (called students' knowledge expectations) during the development of the different workshops. These kinds of questions helped research participants prepare themselves for the reading. Thus, students created some reading expectations that let them focus on the reading in a more 'personalized' way with the purpose of answering questions from the prereading stage.

So far this paper has presented and described what emerged from the analysis of the data. In the following section the reader will find the discussion related to this research report.

\section{Discussion}

The findings of this study demonstrated that students organize information with basically two purposes: the first is related to reading and the second to writing. The former was done with the objective of understanding the text and classifying the information into main and supporting ideas. The latter was used to organize information participants were going to include in their written articles. It was also possible to analyze what information learners included in their written reconstructions and the connections made between previous and new knowledge.

Students had acquired knowledge about this topic not only at school but also at home as part of their personal interests and preferences. It could be argued from the sub categories School Knowledge and Making Connections that students made connections from another class, in this case the Energy Transformations (Transformaciones energéticas) Class. This knowledge was acquired at the school as part of the curriculum development. One advantage was that the topics of the Transformaciones Energéticas class and English class were connected and thus learners were able to complement topics addressed in each class.
In relation to the main question about how students reconstruct their texts when using GOs, it is evident from the first category, Declarative Knowledge, that students reconstructed their texts not only using different sources of information such as the Internet, encyclopedias, and discussions with their parents, teachers, or classmates, but also by retrieving information from other subjects. Participants also took into account their previous knowledge (the general ideas they had about a given topic); moreover, they included information contained in the articles. Participants looked for extra information on the Internet to clarify and complement concepts. Learners used the GOs to organize information into main and supporting ideas.

From the supporting question (What do written productions from students show the ELT community about students' connections to previous knowledge?), participants used GOs to write information they considered most important. Participants did not include examples or extra information that complemented the main ideas. Research participants also followed the written section instructions about how to write an article and included an introduction with the principal idea, paragraphs with supporting ideas, and a final paragraph with a conclusion.

The subcategories Making Connections and Daily Knowledge show that research participants tried to find more information by asking other people, looking in encyclopedias, taking a second look at previous courses materials, and searching for information such as articles, diagrams, or pictures on the Internet.

In the second category, Knowledge coconstruction, the pre-GOs helped students retrieve previous concepts they had about the human body systems. GOs were also used to organize information contained in different texts. Students' written productions showed that participants included the most relevant information in their 
writing; they identified main organs or processes that let them recognize ideas and relationships among concepts. As mentioned before, students included different types of information in their written productions. According to the subcategory Making Connections, research participants took into consideration not only their prior knowledge but also information included in articles read and information provided by parents. Moreover, they looked for extra information in order to complement their prior ideas. Students used their previous knowledge as a starting point. In other words, students based their writing on knowledge they had and then complemented their initial ideas with new information.

Previous knowledge not only serves to activate prior concepts and prepare students for new information but also serves as a starting point for writing. Research participants included information they indicated as prior knowledge during the pre-focus groups in their rewritten productions.

\section{Final Considerations}

Certainly no method, technique, strategy, or tool is perfect; there are always drawbacks. In this case, it was difficult to introduce new kinds of GOs to the students' classroom practices. At the school, students work with a type of GO called "mentefacto" or mind fact. This type of GO is very stiff and does not allow students to include their ideas or points of view. This GO consists of a supra-ordinate concept, a sub-ordinate concept, some derivate concepts, and some exceptions. I had some problems including network trees and brain storming GOs because students were used to working with mind fact GOs. When I introduced new kinds of GOs students continuously asked, "Where do we have to include the supra-ordinate? Where can we write the derivate concepts?" In the third workshop one of the research participants did not use the brain storming GO; instead, she created her own "mentefacto"; she mentioned that she did her own GO and included supra- and sub-ordinate concepts.

I strongly believe that students reconstructed their texts based on several aspects. First of all, participants had previous concepts that let them analyze, interpret, and complement new ideas presented in a text, which is how people make associations between prior and new ideas. Another aspect that students took into consideration was information presented in the different articles. People write not only based on their ideas, but also based on ideas presented in a reading or on other people's ideas. In this way, people complement, reshape, reorganize, and reconstruct their knowledge. It is important to recognize that the research participants used different sources of information to enrich and complement their texts.

\section{Conclusion}

This research study suggests that learners have previous ideas or knowledge that allow a teacher to introduce a topic and analyze what students know in order to complement, organize, or re-direct a given topic. This research will be useful to other teachers when taking into consideration that students' knowledge could help teachers shape their teaching contents and/ or practices.

Both the students and the researcher were engaged and motivated to face real texts written in English. Students felt confident about their reading comprehension and written productions. Students at the basic level demonstrated they could: a) handle middle length expository texts; b) comprehend academic texts related to anatomy; c) rewrite expository texts in English based on previous knowledge and connections established between prior and new concepts; and d) identify main and supporting ideas and show differences between principal ideas and details in the text. 
As participants mentioned in the post-focus groups of the first, third, and fourth workshops, GOs served not only to organize information in a systematic way but also to compare and contrast concepts and establish hierarchies. Thus, teachers could include them as part of their teaching practices in order to help second language learners organize and categorize information.

Students can benefit from using GOs because they learn how to organize information and establish relationships among concepts. Taking into account that learners relate information contained in a text with previous ideas or knowledge, it would be easier for students to retain new information by using GOs. Learners can also comprehend texts better because they can identify and represent the semantic structure of a text, which gives them a general idea about the text and how the information is related.

Authors such as DiCecco and Gleason, Jiang and Grabe, and Robison and Kennet agree that the use of GOs for developing reading comprehension has generated some misunderstandings in terms of purposes, uses, and results. They concur that GOs have several uses; hence, it has been difficult to reach an agreement about their application and final purposes. These authors also mention that because there are different kinds of GOs and each kind has a determined goal, the use of GOs depends on the teacher or researcher aims. Even though the use of GOs has some inconveniences, one cannot negate that there are more benefits than detriments. Through the use of GOs students can develop reading and writing strategies, learn how to organize information, and establish hierarchies by identifying categories and subcategories. Learners can also retrieve previous knowledge and make connections with new information. Teachers and researchers should not ignore the opportunity to work with visual representations that help students organize, connect, and relate information. Students comprehend texts better because they understand main and supporting ideas, focus on the more relevant aspects, and omit details and examples. While using GOs to organize information, establish hierarchies among concepts, or identify the text semantic structure, students do not pay special attention to vocabulary or grammar structures; instead, students concentrate on comprehension and look for general ideas, theses, arguments, and main and supporting ideas. Students do not focus on the form, but instead on the content.

On the other hand, it is necessary to have training periods for both teachers and students in order to learn how to create and use different kinds of GOs. Teachers cannot assume that learners know how to manage GOs. If teachers do assume this, learners may presuppose that they are able to include whatever they want; they may also focus on the form rather than on the content. Teachers must have clear purposes in mind to guide learners and in this way it will be possible to accomplish the initial aims.

Using readings, teachers can incorporate topics from other subjects and teach the language through real-world content and information rather than with grammatical emphasis. Taking into account that reading strategies will be useful for further educational and professional activities, working with content and real-world reading can help learners prepare for future studies and professional careers.

\section{References}

Alderson, C. (2000). Assessing reading. Cambridge: Cambridge University Press.

Brown, J. (2002). Understanding research in second language learning. Cambridge: Cambridge University Press.

Burns, A. (2001). Collaborative action research for English language teachers. Cambridge: Cambridge University Press.

Buzan, T. (1996). The mind map book. New York: Penguin Books.

Carretero, M. (2005). Constructivismo y educación. Buenos Aires: Editorial Luis Vives. 
Campos, A. (2005). Organizadores gráficos. Técnicas visuales para aprender y enseñar. Revista Internacional del Magisterio. $N^{\circ}$ 18. Bogotá: Cooperativa Editorial del Magisterio.

DiCecco, V. \& Gleason, M. (2002). Using GO to attain knowledge from expository text. Journal of Learning Disabilities. (35)4.

Gökler, F., Özay, E., Öztas, F., \& Öztas, H. (2006). The improvement of ecology teaching in secondary school: effects of concept maps in the restructuring of previous knowledge. Journal of Science Education. (7)2. p. 115-118.

Goodman, K. (1996). On reading. Portsmouth: Heinemann.

Lankshear, C. \& Knobel, M. (2004). A hand bookfor teacher renew search: from design to implementation. New York: Open University Press.
Lerner, D. (2001). Leer en la escuela: lo real, lo possible y lo necesario. México: Fondo de Cultura Económica. Ministerio de Educación Nacional. (2005). Bases para una nación bilingüe y competitiva. Al tablero $\mathrm{N}^{\circ} 37$. Retrieved April 15 2009. From:_http://www.mineducacion.gov.co/1621/article-97498.html

Moss, B. (2004). Teaching expository text structure through information trade book retellings. The Reading Teacher. (57)8. p. $710-718$.

Nunan, D. (2002). Research methods in language learning. Cambridge: Cambridge University Press.

Omaggio, A. (1993). Teaching language in context. New York: Heinle \& Heinle.

Wallace, J. (2002). Action research for language teachers. Cambridge: Cambridge University Press.

White, R., \& Arndt, V. (1996). Process writing. Harlow: Longman.

THE AUTHOR

ELSY CAMILA REYES Elsy Camila Reyes holds a B.A in Philology and Languages from Universidad Nacional de Colombia, and a Masters degree in Applied Linguistics to TEFL from Universidad Distrital. She is currently an English teacher in Colegio Nuestra Señora de Pilar Sur, in Bogotá, Colombia. 